\title{
İnfantil Kolik Tanı ve Tedavisinde Güncel Yaklașımlar
}

\author{
New Approaches in the Diagnosis and Treatment of Infantile Colic
}

Filiz Șimșek Orhon ${ }^{1}$ Ankara Universitesi Tıp Fakültesi Sosyal Pediatri Bilim Dalı, Ankara,
Türkiye
Geliș Tarihi : 25.01.2016• Kabul Tarihi: 10.03.2016

Iletișim

Doç. Dr. Filiz Orhon

E-posta: simsekfiliz@hotmail.com Tel: 5957202

Faks: 3191440

Ankara Üniversitesi Tıp Fakültesi Sosyal Pediatri Bilim Dalı

Bebeklik döneminde ağlama düzenleyici bir ișlevdir. İnfantil kolik; sağlıklı büyüyen bir bebekte günün belirl saatlerinde meydana gelen, 3-4. aya kadar devam eden ve hiçbir nedene bağlanamayan ağlama krizleridir. Infantil kolik sıklığı \%10-40 arasında olup kesin nedeni bilinmemektedir. Etiyolojide; gastrointestinal, nörogelișimsel ve psikososyal nedenler tartıșılmaktadır. Kolikli bebeklerde fiziksel istismar riskinin artmıș olduğu, hiperaktivite ve akademik zorluklar gibi davranıșsal sorunların görüldüğü bildirilmektedir. Ayrıca kolikli bebeğin ebeveyninde tükenmișlik, yorgunluk ve depresyon gibi bulguların gelișebileceği bildirilmektedir. İnfantil kolikli bebeğe yaklașımda; bebeğin ağlamasının süresi ve șiddeti ve ağlama krizine eșlik eden özellikler ayrıntılı olarak değerlendirilmelidir. Bebeğin ayrıntılı bir muayenesi yapılmalı, büyüme ve gelișimi değerlendirilmelidir. Diğer hastalıkların dıșlanması sonucunda infantil kolik tanısı konduğunda aileler ayrıntılı olarak bilgilendirilmelidir. Infantil kolik tedavisinde uygulanan yaklașımlar; beslenme önerileri, alternatif besinler, farmakolojik tedavi, fiziksel destek tedavileri ve davranıșsal tedavilerdir. Çalıșmalarda; infantil koliğin tedavisinde etkinliği kesin olarak kanıtlanmıș bir tedavi yöntemi bulunmamaktadır. Ailelerin koliğin genellikle geçici bir durum olduğu konusunda bilgilendirilmesi, rahatlatılması ve desteklenmesi çok önemlidir.

Anahtar Sözcükler: Infantil Kolik, Tanı, Tedavi

Crying during infancy is a regulatory function. Infantile colic may be defined as crying episodes in healthy children, which occurs during some hours a day, lasts for 3 to 4 hours, and cannot be linked to any cause. The frequency of infantile colic is $10-40 \%$ with an unknown precise cause. In terms of etiology, the points under discussion are gastrointestinal, neurodevelopmental, and psychosocial causes. It is reported that colicy infants have increased risk of physical abuse and are observed to have behavioral problems like hyperactivity and academic difficulties. It is further reported that findings such as exhaustion, weariness and depression are likely to develop in the parents of colicy infants. In the treatment of infants with infantile colic, the duration and severity of crying, as well as other features which accompany a crying episode should be evaluated in detail. An affected infant should be examined in detail and evaluated in terms of growth and development. When a diagnosis of infantile colic is made following the exclusion of other possible diseases, the families should be advised accordingly. The approaches in the treatment of infantile colic are dietary recommendations, alternative foods, pharmacologic therapies, physical supportive treatments, and behavioral therapies. There is no such treatment available for infantile colic, which has a proven efficacy. It is quite significant to advise the affected families in that colic is typically a temporary condition and to relieve and support them accordingly.

Key Words: Infantile Colic, Diagnosis, Treatment

\section{INFANTIL KOLIK}

\section{Bebeklerde normal ağlama}

Ağlama, bebeklik döneminde düzenleyici bir işlev olup bebeklerin çevre ile iletişimini sağlayan bir yoldur. Hayvan ve insan çalışmalarında anatomik olarak değerlendirildiğinde; ağlamanın subkortikal yapılardan kaynaklandı̆̆ı gözlenmiş, bebeklerde ağlamanın akciğer kapasitesini ve motor etkinliği artırdığı ve vücut sıcaklığını dengelediği bildirilmiştir (1).

Doğumu izleyen ilk üç ayda aşırı ağlama bebeklerde çok sık rastlanan bir yakınmadir. Bebeklerin gün içindeki ağlamaları ilk başta düzensiz olup ağlamaların özellikle akşam saatlerinde arttığ1 gözlenmektedir. Normal ağlama doğumdan itibaren ilk haftalarda başlayıp 6-8. haftalara doğru günde en fazla 23 saate kadar ulaşan ağlamadır. Ağlamanın tipi ve süresi bebekler arasında değişkenlik göstermekle birlikte, normal ağlama patterni 2 haftalık bir bebekte günde ortalama 2 saat, 6 haftalık bebekte 3 saat ve 3 aylik bir bebekte 1 saattir. Çoğu bebekte ağlama ve huzursuzluk kendiliğinden 3-4. aylardan sonra azalarak kaybolur $(1,2)$.

\section{Tanım ve epidemiyoloji}

İnfantil koliğin gelişimsel ağlama paterninin bir varyantı olabileceği konusunda görüşler bulunmakta ve bu klinik du- 
rum çeșitli şekillerde tanımlanmaktadır. Sağlıklı büyüyen bir bebekte genellikle doğumdan 2 hafta sonra ortaya çıkan, günün belirli saatlerinde meydana gelen, 3-4. aya kadar devam eden ve hiçbir nedene bağlanamayan ağlama krizleri infantil kolik olarak adlandirılmaktadır $(3,4)$. Wessell ve arkadaşları (5) tarafindan infantil kolik; gelişimi normal olan, sağlıklı 0-3 aylık bebeklerde görülen, en az üç hafta süreli, haftada üç günden, günde üç saatten fazla ve başka bir nedenle açıklanamayan huzursuzluk, ajitasyon ve a $\breve{g}-$ lamaların olduğu klinik tablo olarak tanımlanmaktadır. Fonksiyonel gastrointestinal hastalıklar için belirlenen Roma III kriterlerine göre ise; doğumdan 4 aya kadar olan bebeklerde belirgin bir neden olmadan başlayan ve sonlanan irritabilite, huzursuzluk, ağlama nöbetlerinin varlığ rin günde 3 saat ya da daha uzun süre devam etmesi, en az bir hafta boyunca haftada en az 3 gün görülmesi ve bebekte büyüme geriliğinin eşlik etmemesi infantil kolik kriterleri içinde yer almaktadır (6).

İnfantil kolikli bebeklerde ağlama epizodları sırasında gözlenen çeşitli karakteristik özellikler bulunmaktadır. Bu bebeklerde ağlama epizodlarının genellikle geç öğleden sonra ve akşamları ortaya çıktığı gözlenir. Kolikli bebeklerde ağlama genellikle paroksismal olup aniden ve nedensiz başlar. Ağlama yüksek sesle, dindirilemeyen ve aşırı şekilde olup bebek rahatlatılmaya yanıtsızdır ve ağlama epizodları birkaç dakikadan birkaç saate kadar sürebilir. Bebeklerde aşırı ağlamaya eşlik edebilen; yüzde kızarıklık, sımsıkı kapalı ya da çok açık gözler, kızarık ve buruşturulmuş yüz, çatılı kaşlar, bacakları karına çekme, direnme, yumrukları sıkma ve karında gerginlik gibi motor bulgular gözlenebilir. Ağlama nöbeti bebeğin tamamen yorulması ile veya bazı olgularda dışkı veya gaz çıkarması ile sonlanmaktadır $(4,7)$.

İnfantil kolik nöbetleri bebekler arasında farklılıklar olmakla birlikte; genellikle yaşamın ikinci haftasında başlar, gittikçe şiddetlenerek 4-8. haftalarda pik yapar ve yavaş yavaş azalarak genellikle üçüncü ayın sonunda kaybolur. Yapılan çalışmalarda; olguların
$\% 90$ 'nnda 4. ayın sonunda kolik belirtilerinin kaybolduğu bildirilmiştir $(7,8)$.

Ağlama, bebeklik döneminde sık rastlanan semptomlardan olduğundan infantil koliğin kesin sıklığını belirlemek zordur. Çalışmalarda infantil kolik sıklığı \%9-40 arasında bildirilmektedir (3). İnfantil kolik sıklığı prospektif çalışmalarda \%3-28, retrospektif çalışmalarda ise \%8-40 olarak saptanmıştır. Poliklinik pratiğinde; üç ayın altında bebeği olan her 6 aileden birinin bebeğinin fazla ağlaması nedeniyle başvurduğu belirlenmiştir (9).

\section{Etiyopatogenez}

İnfantil koliğin kesin nedeni bilinmemekle beraber gastrointestinal, nörogelişimsel ve psikososyal nedenleri içeren çeşitli hipotezler öne sürülmüştür.

\section{Gastrointestinal nedenler:}

Son y1llarda fonksiyonel gastrointestinal hastalık tanıminin belirlenmesi, bu durumun patogenezinde enterik sinir sistemi-duyarlı çocuk olarak adlandırılan hipotezlerin tartışılmasına yol açmıştır. Bu hipoteze göre; fetal periyotta ve postnatal dönemde gastrointestinal sistemde modifikasyonlar görülebileceği ve stres, enfeksiyonlar ve beslenme gibi etmenlerle bu sistemin değişikliğe uğrayabileceği öne sürülmektedir. Bu değişikliklerin infantil kolik etiyolojisinde de rol oynadığ 1 ve ileri aylarda maturasyonla birlikte kolik semptomlarının ortadan kalktığı araştırıcılar tarafindan öne sürülmüştür (10).

Önceki çalışmalarda; aerofaji ve emilemeyen karbohidratların kolonik bakteriyel fermentasyonuna bağlı olarak barsak lümeninde gaz artışının ve bunun oluşturduğu gerginliğin kolik etyolojisinde bir neden olabileceği öne sürülmüştür. Fakat çalışmalarda bu durum radyolojik olarak gösterilememiş ve bu hipotezden uzaklaşılmıştır (11).

Barsaklarda gaz basıncına duyarlılığın artmas1, anormal barsak peristaltizmi ve intestinal hipermotilite etiyolojide öne sürülen diğer faktörlerdendir. Önceki çalışmalarda; motilin ve ghrelin düzeyinde artışın intestinal hipermotiliteye neden olduğu, annenin sigara içmesinin motilin düzeyinde artışa yol açtığ1 ve bunun da infantil kolik etyolojisinde öne sürülen bir etmen olduğu tartışılmıştır (12,13). İnflamatuar barsak hastalığ1 etyolojisinde yer alan fetal kalprotektin düzeyindeki farklılıkların barsak inflamasyonuna ve bunun sonucunda infantil koliğe neden olduğu son yıllarda araştırıcılar tarafindan öne sürülmüştür (14).

Besin alerjisinin, özellikle de inek sütü protein alerjisinin infantil kolik etiyolojisinde rol oynayabileceği konusunda çeşitli görüşler ortaya çıkmıştır. Hatta infantil koliğin inek sütü protein alerjisinin ilk bulgusu olabileceği öne sürülmüștür. Fakat bu ilișkinin belirlenmesinde; inek sütü protein alerjisinde saptanan ailede atopi öyküsü, rinit, wheezing, astım gibi atopik sorunların varlığ1, diare, konstipasyon, kusma, gaytada müküs ya da kan varlığ1 ve büyüme geriliği gibi diğer semptom ve belirtilerin mutlaka aranması gerektiği özellikle belirtilmektedir (15). Nocerino ve arkadaşlarının (16) 2015 yılında yaptığı derlemede; atopinin diğer belirtileri olmayan kolikli bebeklerde besin alerjisi varlığının tartışmalı olduğu, yeterli sayıda vaka ile yapılmış ve iyi tasarlanmış çalışmanın olmadığ ve yeni randomize kontrollü çalışmalara ihtiyaç olduğu belirtilmiştir.

İnfantil kolik etiyolojisinde yer aldığı düşünülen diğer gastrointestinal nedenler içinde; gastroözofajiyal reflü, laktoz intoleransı ve beslenme yanlışlikları da suçlanmaktadır. Fakat kolik ağlamaları ile bu klinik durumlar arasındaki ilişkiyi gösterecek kesin kanıt bulunmamiş ve bu klinik sorunlardan şüphelenildiğinde ileri incelemenin yapilması gerektiği önerilmiştir (17).

Barsak mikrobiatası ve bu sistemde oluşan değişikliklerin birçok hastalıkla ilişkili olabileceği son yıllarda öne sürülmektedir. Özellikle antiinflamatuar etkileri olan laktobasiller ve bifidobakterilerde azalmanin, gaz ve enflamasyona neden olan proteobakterilerde ve bütirat üreten türlerde artmanin sonucunda barsak hareketlerinde değişiklik, barsağın inflamatuar yanıtında bozulma 
ve barsaklarda gaz oluşumu olduğu, bunun da infantil kolik etiyolojisinde rol oynadığ 1 öne sürülmektedir $(18,19)$. Fakat araştırıcılar, bu konuda yapılan çalışmalar devam etmekle birlikte kolik patogenezinde barsak mikrobiyatasının belirleyici rolünün tam olarak aydınlatılamadığını, verilerin tartışmalı olduğunu ve bu nedenle iyi planlanmış araştırmalara ihtiyaç olduğunu belirtmektedir (20).

Gastrointestinal etiyoloji tartışllırken, infantil koliğin fonksiyonel bir barsak hastalığ1 mı yoksa gelişimsel bir durum mu olduğu konusundaki verilerin sistematik bir şekilde değerlendirilmesi gereklidir. Koliğin geçici olması etiyolojideki gastrointestinal nedenlerden uzaklaştırmakta olup gelecekte yapılacak çalışmalara ihtiyaç olduğu kabul edilmektedir.

\section{Nörogelișimsel nedenler}

Önceki çalışmalarda; erken yenidoğan döneminde dişarıdan gelen uyarıları engelleyici bir mekanizmanın var olduğu, birinci haftadan sonra bu engelleyici mekanizmanın ortadan kalktığı ve bebeğin dış uyaranlara karşı daha uyanık ve duyarlı hale geldiği öne sürülmüştür. Bu durumun da bebekte kolik gelişiminde rol oynayan nörogelişimsel bir süreç olduğu, bir başka deyişle; uyarıcı sistemin aktif olması buna karşı yatıştırıcı sistemin yeterince aktif olmamasının infantil kolik gelişimine neden olduğu öne sürülmüştür $(3,21)$. Diğer yandan, ilk haftalarda bebeğin frontal loblarının henüz yeterince gelişmemesi nedeniyle zararlı ve hoşa gitmeyen her uyarınin bebek tarafindan ağrı olarak algılanabileceği ve bunun da kolik gelişimine yol açabileceği öne sürülmüştür. Nörogelişimsel olarak araştırıcılar tarafından öne sürülen bir diğer hipotez de; bebekteki immatür nörolojik sistem nedeniyle, duyu sinirlerinin barsak distansiyonuna karşı duyarlı olması, bu durumun uyaranlara karşı yanıtta farklılıklara neden olmas1, bebeğin her uyaranı ağr1 olarak algılayıp yanıt vermesi ve böylece kolik ağlamalarının oluşmasıdır (21).

İnfantil koliğin nörogelişimsel etiyolojisi ile ilgili yapılan çalışmalarda; koliğin bebekte uyku-uyanıklık döngüsü düzenlenene kadar gelișen fizyolojik bir süreç olduğu ve sirkadiyen ritm maturasyonundaki farklılıkların gelişimsel bir süreç içinde infantil kolik oluşumunda rol oynayabileceği de öne sürülmüştür $(3,21)$. Milidou ve arkadaşlarının (22) yaptığ1 ve 2605 preterm ve 54441 term bebeğin izlendiği bir doğum kohortu çalışmasında; gestasyonel yaş küçüldükçe kolik riskinin arttığ1 ve termlere göre preterm ve düşük doğum ağırlıklı bebeklerde infantil kolik riskinde artış olduğu saptanmış ve kolik etyolojisinde prenatal ve perinatal nedenlerin de yer alabileceği tartış1lmıştır.

İnfantil koliğin etiyolojisinde; seratoninmelatonin teorisi de özelikle son yıllarda tartışılmaktadır. Düz kaslar üzerinde seratonin kasilma, melatonin ise gevşeme etkisi göstermekte olup bu hormonların salınımı akşam saatlerinde artmaktadır. Teoriye göre; seratonin etkisinin doğumdan sonra ilk haftalardan itibaren görülmesine karşın melatonin siklusu 3. aydan sonra düzene girmektedir. Bu nedenle, melatonin seratoninin etkisini ilk 3 ay baskilayamamakta ve barsakta kasilmalar ortaya çıkarak kolik oluşmakta$\operatorname{dir}(8)$.

İnfantil koliğin geçici bir seyir izlemesi nedeniyle nörogelişimsel etiyoloji günümüzde birçok araştırmacı tarafından en çok kabul gören etiyolojik neden olarak bildirilmektedir.

\section{Psikososyal nedenler:}

Önceki çalışmalarda; infantil koliğin bebekteki zor mizacin erken bir bulgusu olabileceği ya da yorgun bebeğin yalnız kalma isteği ile ilgili olabileceği öne sürülmüş fakat desteklenmemiştir. Anne ile bebek arasindaki olumsuz ilişkinin ve bağlanma bozukluğunun, ebeveynin anksiyetesinin, gebelikte stres varlığının ve yetersiz ebeveynliğin infantil kolik etiyolojisinde rol oynayabileceği öne sürülmüştür (23). Fakat infantil kolikli bebekler ve ebeveynlerindeki bulgular nedeniyle doğru bir neden-sonuç ilişkisinin kurulmasinın zor olduğu ve tek başına psikososyal etkenlerin etiyolojide önemli olduğuna dair verilerin tartışmalı olduğu araștırıcılar tarafindan bildirilmektedir (3).

Sonuç olarak; infantil kolik etiyolojisinde tek bir nedenin olmadığı, farklı durumların birlikteliğinin kolik semptomlarına neden olduğu öne sürülmekte olup olguların ancak $\% 5$ 'inden azında organik bir neden bulunmaktadır (4).

\section{Infantil koliğin ebeveyn ve bebek üzerine olan kısa ve uzun dönem etkileri}

İnfantil kolikte, ağlama nöbetlerinin sılklı̆g1 ve uzun sürmesi ile birlikte bebeğin beslenme- uyku-dinlenme düzeni bozulabilir ve bebek huysuzlaşabilir (24). Kolikli bebeklerin ebeveynlerinde özellikle annede; çaresizlik, yorgunluk, uykusuzluk, konsantrasyon bozukluğu, tükenme, özgüven yitimi, yetersizlik duygusu, kayg1 ve emzirme sorunları gibi bulgular ortaya çıabilir. $\mathrm{Bu}$ annelerde depresyon sıklığının da arttığ1 çalışmalarda gösterilmiştir $(24,25)$.

Önceki çalışmalarda aşırı ağlamanın sarsılmiş bebek sendromu, ihmal ve istismar için tetikleyici bir etmen olduğu bulunmuştur. Altı aya kadar bebeği olan ebeveynlerin \%5.6'sının sarsılmış bebek sendromuna neden olacak manevraları bebeklerine uyguladıkları saptanmıştır $(26,27)$.

Son y1llarda araştırmalarda infantil koliğin olası uzun dönem etkileri ile ilgili tartışmalar yapılmaktadır. Bazı araştırıcılar koliğin geçici bir durum olduğunu ve uzun dönem etkilere neden olmad1ğını; bazıları ise koliğin uzun dönem etkileri ile ilgili veriler olduğunu öne sürmektedir (28). İnfantil koliği olan bebeklerin yaşamlarının ileri döneminde tekrarlayan karın ağrıları, başağrıları, fonksiyonel barsak hastalığ ve allerjik bozukluklar gibi klinik durumları daha fazla yaşadıkları belirtilmektedir. Erken bebeklik döneminde oluşan ağr1 deneyimlerinin daha sonraki yaşlarda ağrı yanıtında değişikliğe neden olması bu tip uzun dönem etkilerin altında yatan mekanizma olarak öne sürülmektedir (29,30). Indrio ve arkadaşlarının 2015 yılında yaptığı, 2987 hasta ve 3121 kontrolu içeren 
retrospektif bir çalışmada; erken bebeklik döneminde kolik, regürjitasyon ve konstipasyon gibi sorunlar yaşayan kronik ve tekrarlayan semptomlarla karakterize fonksiyonel barsak hastalı̆̆1 gözlendiği bildirilmiştir.

İnfantil koliği olan bebeklerde ileri bebeklik ve çocukluk evrelerinde kolaylikla ağlama, negatif mizaç özellikleri, yeme sorunları, hiperaktivite, akademik zorluklar ve uyku sorunları gibi davranışsal ve bilişsel sorunların daha sıklıkla ortaya çıktığ1 çalışmalarda gösterilmiştir. Kolikli bebeklerde gözlenen davranışsal ve bilişsel sorunların özellikle kolik semptomları 6 aya kadar devam eden bebeklerde daha siklikla olduğu da araştırmalarda gözlenmiştir (32,33).

İnfantil koliğin, ileri dönemde gelişen migrenle de ilişkili olabileceği konusunda tartışmalar mevcuttur. Başağrılarının s1nıflaması ile ilgili yapılan çalışmalarda; sorders (ICHD-III beta) içerisinde infantil kolik "Migrenle ilişkili olabilen epizodik sendromlar" grubuna alınmıştır. İnfantil koliğin, migrenöz hastalıkların yaşamın erken döneminde ortaya çlkan bir klinik görünümü olabileceği öne süfenomeninden yararlanılabileceği konusunda öneri verilmiştir (34). Gelfand ve arkadaşlarının (35) 2015 yılında yaptığ1 bir metaanaliz incelemesinde; bu konuda yapılmış çalışmalarda migren ve infantil kolik arasinda kuvvetli bir çocuklarda ileri yaşlarda daha sıklıkla International Classification of Headache Dirülmüş ve tedavi yaklaşımında migren

ilişki olduğu bulunmuş ve infantil koliğin çocukluk çağı migreni ile ilişkili olduğu öne sürülmüştür.

\section{Tanı}

Infantil kolikli bebeğe tanı koymada ve yaklaşımda ebeveynden iyi bir anamnez almak en önemli ve ilk basamaktır. Ağlama epizodlarının ne şekilde başladığı, sıklığı, gün içinde ağlama epizodlarının görüldügü zaman, epizodların süresi, şiddeti, eşlik eden özellikler, ağlama epizodlarının ne şekilde sonlandığ1 ve bu ağlama epizodlarından sonra iyi bir dönemin gelip gelmediği ayrıntılı olarak sorgulanmalıdır. İzlemde olan bebeklerin ebeveynlerinden günlük olarak bu epizodların ne zaman başladığını, süresini ve özelliklerini kaydetmesi de istenebilir. Bebeğin ağlaması hakkında anne-babanın düşüncesinin ayrıntılı olarak değerlendirilmesi, ebeveynler ve bebek arasındaki ilişkinin değerlendirilebilmesi açısından çok önemlidir. Varsa ağlamaya eşlik eden diğer semptomlar sorgulanmalı ve ayrıntılı bir gebelik ve doğum öyküsü alınmalıdır (8).

Tanı koymada diğer önemli basamak; bebeğin ayrıntılı bir muayenesinin yapılması ve büyüme ve gelişiminin değerlendirilmesidir. Regürjitasyon, apneik ya da siyanotik ataklar, ateş, solunum zorluğu, ağırlık artımında yavaşlama, nörolojik bulgular varlığ1, diyare, kusma, egzema ve istismar bulguları gibi semptomlar varlığında mutlaka

Tablo 1. Bebekte şiddetli ağlama ve huzursuzluk nedenleri.

\begin{tabular}{|l|l|}
\hline Nedenler & Klinik durumlar \\
\hline Enfeksiyonlar & Otitis media, idrar yolu infeksiyonu, stomatit, menenjit \\
\hline Gastrointestinal sorunlar & $\begin{array}{l}\text { Peristaltizm sorunları, kabızlık, gastroözofageal reflü, } \\
\text { invajinasyon, herni, pilor stenozu, rektal fissür }\end{array}$ \\
\hline Travma & $\begin{array}{l}\text { Korneal abrazyon, gözde yabancı cisim, kırıklar, subdural } \\
\text { hematom }\end{array}$ \\
\hline Kardiyovasküler nedenler & Aritmi (supraventriküler tașikardi), konjestif kalp yetersizliği \\
\hline Beslenme & Beslenme sorunları, besin allerjileri \\
\hline Hematolojik nedenler & Anemi, orak hücre anemisi krizi \\
\hline $\begin{array}{l}\text { Solunum sistemi ile ilgili } \\
\text { sorunlar }\end{array}$ & Koanal atrezi, laringomalazi \\
\hline Nörolojik nedenler & West sendromu, infantil migren \\
\hline Reaksiyonlar & Așı reaksiyonu, yenidoğanlarda ilaç yoksunluğu \\
\hline Çocuk istismarı ve ihmali & $\begin{array}{l}\text { Fiziksel, cinsel, duygusal istismar ve ihmal, sarsılmıș bebek } \\
\text { sendromu }\end{array}$ \\
\hline Çevresel nedenler & $\begin{array}{l}\text { Așırı sıcak ortam, așırı uyarılma, gece sık uyandırılma, mekanik } \\
\text { nedenler }\end{array}$ \\
\hline
\end{tabular}

ileri inceleme yapılmalıdır. Bunun d1şında ağırlık artımı iyi olan ve fizik muayenesi normal olan bebeklerde laboratuar ve radyolojik incelemelere genellikle gerek bulunmamaktadır $(3,8)$. Diğer yandan; Freedman ve arkadaşlarının (36) yaptığ1 retrospektif bir çalışmada; çok ağlayan bebeklerde öykü ve fizik muayenenin en önemli tanısal değerlendirme araçları olduğu, fakat öykü ve fizik muayenesi normal olan çok ağlayan bir bebekte tek yararlı laboratuar testinin idrar analizi olabileceği öne sürülmüştür.

Bebekte aşırı ağlama ile ortaya çıkan birçok durum ayırıcı tanıda önemlidir. Tablo 1, bebekte aşırı ağlama ile giden sorunlar ve klinik durumları göstermektedir. Bu hastalıkların ve sorunlarin ayırıcı tanısının yapılması kolik tanısının konmasinda en önemli basamaklardan biridir $(8,37)$.

Çok ağlayan bir bebekte tipik öykü özellikleri varsa, bebek sağlıklı görünüyorsa, fizik muayenesi doğal ise ve ağırlık artımı iyi ise tanı infantil kolik olarak konur. Son yıllarda araştırıcılar, infantil kolik fonksiyonel barsak hastalıkları sınıflandırmasında yer aldığından dolayı, altı aydan sonraya uzamış ve ciddi kolik semptomlar1 olan bebeklerin fonksiyonel barsak hastalığ1 açısından değerlendirilmesini önermektedir (3).

\section{Yaklașım ve Tedavi:}

Huzursuz ve çok ağlayan bebeklerde diğer hastalıkların dışlanması sonucunda infantil kolik tanısı konduğunda bebeğin ebeveynine uygun danışmanlık ve bilgilendirme yapılması tedavi ve yaklaşımın ilk basamağı olmalıdır. Bebeğin sağlıklı büyüdüğü ve sağlıklı olduğu, kolik semptomlarının kendiliğinden geçeceği ve bebeğin gelişiminde ve büyümesinde genellikle soruna yol açmadığı konusunda bilgilendirme yapılmalıdır. Ayrıca bebeğin ağlamasının diğer nedenleri, aşırı ağlamaya başlamadan önce yapilması gerekenler ve bebeklerini sarsmamalar1 konusunda aileyi bilgilendirme mutlaka gereklidir. Kolikli bebeklerin anne ve babalarına dinlenme zamanı verilmesi, anne-babanın anksiyete ve psikososyal stres durumunun 
değerlendirilmesi ve gerekirse ailenin desteklenmesi ileri dönemde oluşabilecek olumsuz durumların önlenmesi aç1sından çok önemlidir $(7,36)$.

İnfantil koliğin tedavisinde birçok yöntem denenmiş olup şu ana kadar yapilan çalışmalarda kolik tedavisinde kesin bir fikir birliği sağlanamamıştır. Etiyoloji multifaktoriyel olabileceğinden tedavinin de çok yönlü yapılması önerilmekte ve spesifik tedavinin olgudan olguya değişebileceği bildirilmektedir (4). Infantil kolik tedavisinde yaklaşımlar; beslenme önerileri/değişiklikleri, alternatif besinler, farmakolojik tedavi, fiziksel destek tedavileri ve davranışsal tedaviler başlıkları altında incelenmiştir $(8,38)$.

\section{Beslenme önerileri ve diyet değișikliği:}

İnfantil kolikli bebeklerde ve annelerinde diyet değişikliği uzun yıllardır denenen ve zaman zaman başarılı sonuçların alındığ1 tedavilerdendir. Tek başına anne sütü ile beslenen kolikli bebeklerde anne sütü başlica koruyucu faktör olup diyet değişikliği yapmaya gerek yoktur. Diğer yandan, anne sütü alan bebeklerde; inek sütü proteini alerjisinin dişlanamadığı ve diğer semptomların olduğu durumlarda anneye 2 hafta boyunca hipoalerjenik diyet verilmesinin bazı olgularda kolik semptomlarını gerilettiği öne sürülmüştür. Hipoalerjenik diyet annenin diyetinden süt ve süt ürünleri, buğday, yumurta ve findik gibi alerjen besinlerin çıkarılmasıdır. Bu diyet sırasında annenin besinlerle yeterli vitamin ve mineral desteği aldığına emin olunmalı ve 2 haftadan sonra yarar gösterilemezse diyet düzenlenmesi sonlandır1malidir (39).

Anne sütü almayan ve mama alan kolikli bebeklerde atopi öyküsü ve semptomu varsa bebeğe hipoalerjen mamalar önerilmektedir. Özellikle ciddi koliği olan çocuklarda inek sütü protein alerjisi varsa iki haftalık hipoalerjenik diyet önerilmektedir. Buna karşın, araştırıcılar kolikli bebeklerde besin alerjisi şüphesinde hidrolize mama ya da maternal diyet eliminasyonu uygulandığında klinik izlemin iyi olması gerektiğini ve sonuç alınamazsa besin müdahalesinin sonlandırılması gerektiğini bildirmektedir (16).

Kolikli bebeklerin diyet düzenlenmesinde soya bazlı mamalar fitoöstrojen içermesi ve geç başlayan inek sütü protein alerjisinde çapraz reaksiyon varlığı nedeniyle önerilmemektedir. Aynı şekilde standart mama ile yeterli ağırlık artımı var ve inek sütü proteini alerjisi öykü ve semptomu yoksa hidrolize mamaya geçiş önerilmemektedir (40). Kolikli bebeklerde laktaz enzimli ya da liften zengin mamaların ve laktaz enziminin kullanımı ile ilgili yeterli veri olmadığı da çalışmalarda gösterilmiştir (38).

Son yıllarda probiyotiklerin infantil kolik tedavisinde kullanımı ile ilgili yayınlar artmaktadır. Bu araştırmalarda sonuçlar arasinda farkliliklar mevcut olup etkinlik konusundaki veriler tartışmalıdır. Chau ve arkadaşlarının (41) 2015 yılında yaptığı yeni bir çalışmada; anne sütü alan bebeklerde $L$. Reuteri verildiğinde kolik semptomlarında düzelme olduğu saptanmıştır. Sung ve arkadaşları (42) tarafindan yapılan bir metaanaliz çalışmasında 12 randomize kontrollü çalışma değerlendirilmiştir. Bu metaanalizde; çalışmalarda yanlılıklar, metodlarda düzensizlikler ve infantil kolik tanısı koymada hataların mevcut olduğu, kolik semptomlarının tedavisinde veya koliğin önlenmesinde probiyotiklerin kullanılmasını destekleyen yeterli verinin olmadığı öne sürülmüştür. Anabrees ve arkadaşlarının (43) yaptığ1 sistematik derlemede; probiyotiklerin anne sütü alan bebeklerde kullanımı ile olumlu etkilerin görülebileceği, buna karşın mama alan bebeklerde etkinliğinin tartışmalı olduğu öne sürülmüş ve bu konuda yapılacak geniş populasyonlu çalışmalara ihtiyaç olduğu belirlenmiştir.

Sonuç olarak; infantil kolik tedavisinde besinsel yaklaşımların süt çocuklarının çok az bir kısmında etkili olabileceği gösterilmiştir. Besinsel yaklaşımların etkisini kesin olarak ortaya koymak zor olup uygulanmasinda tehlikeler olabileceği bildirilmektedir. $\mathrm{Bu}$ nedenle besin alerjisi tanısından kesin emin olunmadıkça kolikli bebeklerde hipoalerjenik mamalar denenmemelidir. Ayrıca anne sütü alan kolikli be- beklerde kesinlikle mama denenmemeli ve annenin hemen diyete girmesinden kaçınılmalıdır (44). İnfantil kolikte; anne sütü alan bebeklerde emzirmenin devamının sağlanması ve desteklenmesi, her emzirmede bir memenin tamamen boşaltılmasının sağlanmas1, formula ile beslenenlerde uygun biberon kullanımı, beslenmeden sonra gazının iyi çıkarılması, annenin diyetinde kafein içeren içeceklerin azaltılması ve sigara içmemesi gibi genel öneriler konusunda da annenin bilgilendirilmesi önemlidir (45).

\section{Alternatif besinler:}

İnfantil kolik tedavisinde bitkisel çaylar yıllardır kullanılmakta ve bazı olumlu etkilerinin olabileceği öne sürülmektedir. Kolik tedavisinde önerilen bitkisel çaylar grubunda rezene, papatya, mine çiçeği, meyan kökü, limon yağı, tarçın, karanfil, dereotu, zencefil, nane, civanperçemi, kakule, ıhlamur, kedi nanesi ve sinameki gibi ürünler mevcuttur. Fakat bu tedavilerin kullanımında çekinceler mevcuttur. Bu çekinceler; bitkisel çayların doz ve içeriklerinin standardize olmaması, anne sütü ile beslenmeyi bozmaları ve içerdikleri alkol vb toksik maddelere bağlı ciddi yan etki varlığıdır. Ayrıca bu çayların ve bitki karışımlarının kullanımının kolik semptomlarını azalttığına dair kesin kanıtların olmadığı da çalışmalarda bildirilmiştir (44).

Alternatif besinler içinde oral sükroz kullanımı bir dönem önerilmiş olup çalışmalarda bu konuda yeterli verinin olmaması nedeniyle artık rutinde önerilmemektedir (46). Son yillarda denenen alternatif yöntemler içinde yer alan homeopatik yöntemlerin ise bebekte hayatı tehdit eden yan etki riski taşıması nedeniyle önerilmemesi gerektiği araştırıcilar tarafindan bildirilmektedir (47).

Alternatif besinlerin kolik tedavisinde kullanımı ile ilgili olarak Perry ve arkadaşlarının (48) yaptığı sistematik derleme çalışmasında bitkisel çaylar ve şeker solusyonlarının kolik tedavisinde etkili olduğunu gösteren kontrollü çalışmanın az sayıda olduğu, çalışmalarda sınırlılıkların mevcut olduğu ve bu konuda yeterli kanıtın olmadığı belirtilmiştir. 


\section{Farmakolojik tedavi:}

Infantil kolik tedavisinde uzun y1llardır hem araştırmalarda hem de rutinde çeşitli farmakolojik tedaviler denenmiş olup bu ilaçların etkinliği ile ilgili yeterli kanıtın olmadığı ve hatta ciddi yan etkilere neden olabileceği bildirilmiştir. Bu amaçla kullanılan antispazmodikler ile ilgili olarak kontrollü çalışma yoktur ve süt çocuklarında apne ve solunum problemlerine neden olabileceği bildirilmiştir. Antikolinerjiklerin peristaltik aktiviteyi azaltarak kolik tedavisinde etkili olabileceği öne sürülmüş olmakla birlikte bu grup içinde yer alan disiklomin hidrokloridin solunumsal bulgular, konvülsiyon, senkop, nabızda düzensizlik, hipotoni ve koma; cimetropium bromidin ise uyku hali gibi ciddi yan etkilere neden olabileceği bildirilmiştir. Kolik tedavisinde bir dönem önerilmiş olan sedatifler ve analjeziklerin ise aşırı uyumaya neden olabileceği çalışmalarda gösterilmiştir $(3,7,8)$. Bütün bu ciddi yan etki riski nedeniyle sayılan bu farmakolojik ajanların kolik tedavisinde kullanımı günümüzde önerilmemektedir.

Farmakolojik ajanlar içinde yer alan ve mukusun yüzey gerilimini azaltarak barsaktan gaz atılımını kolaylaştırdığı için kolik tedavisinde önerilen simetikonun randomize kontrollü çalışmalarda plaseboya göre üstünlüğü bulunmamış ve etkisinin olmadığı belirlenmiştir $(7,8)$.

\section{Fiziksel destek tedavileri:}

İnfantil kolik tedavisinde son y1llarda kriyopraktik spinal manipulasyon, kraniyal osteopati ve akupunktur gibi fiziksel destek tedavileri denenmektedir. $\mathrm{Bu}$ tedavilerin gastrointestinal motilitede artış yolu ile bebeğin rahatlamasını sağladığı öne sürülmekle birlikte etkinliği ve güvenliği konusunda yapilmış yeterli çalışma bulunmamaktadır (49). İnfantil kolik tedavisinde kullanılan kriyopraktik ve osteopatik manipulatif tedavilerle ilgili olarak yapılan 6 çalışmanın değerlendirildiği bir Cochrane metaanalizinde; çalışmaların şeklinde sorunlar olduğu ve kolik tedavisinde bu uygulamaların etkinlik ve güvenliği ile ilgili yeterli kanıtın olmadığı saptanmıştır (50). İskandinavya'da infantil kolik tedavisinde s1klıkla kullanılan akupunkturun etkinliği ile ilgili olarak 2013 yilında yapılan bir randomize kontrollü çalışmada; çalışma ve kontrol grupları arasında ağlama süresi ile ilgili farklılık bulunmamıs ve akupunkturun infantil kolik tedavisinde etkinliği gösterilememiştir (51).

\section{Davranıssal tedavi:}

İnfantil kolik tedavisinde davranışsal tedavi uzun yıllardır kullanılan bir tedavi şeklidir. Davranışsal tedavinin etkinliğini iyi düzenlenmiş çalışmalar ile göstermek zordur. Fakat ucuz ve güvenli bir yöntem olduğundan araştırıcılar önerilmesinde sakınca olmadığını bildirmektedir. Davranışsal tedavi yöntemleri içinde; bebeği aşırı uyarılmaktan ve yorulmaktan korumak, günlük düzeni sağlamak, kolik nöbetleri sırasında bebeği ritmik şekilde sallamak, arabasıyla gezdirmek, bebeği kanguru içinde ya da annenin/bakıcının kucağında göğsüne yaslanmış şekilde tutmak, sıkıca ve kundaklar gibi sarmak, sarılmak, sırtına, hafifçe, aralıklı olarak minik vuruşlar uygulamak, karına sicak havlu uygulamak, 1lik banyo yaptırmak, şarkı söylemek, masaj yapmak ve vantilatör, elektrik süpürgesi, saç kurutma makinesi ve doğadaki seslere benzeyen ritmik sesler (beyaz gürültü) dinletmek gibi yöntemler bulunmaktadır (3).

Davranışsal tedavi amacıyla rutinde kullanılan 5S yöntemi içinde; swaddling (sarmak, battaniye veya örtü ile sıcak tutacak şekilde kalça fleksiyona gelecek şekilde sarmak), side or stomach (yan ya da midenin üzerine yatırmak), shbh sound (bebeğin kulağına fisıldamak), swinging the baby with tiny jiggly movements (hafif hareketlerle sallamak) ve sucking (memeye koymak veya parmak, emzik vermek) yer almaktadır (52).
İnfantil kolik tedavisinde kullanılan bütün tedavi yöntemleri göz önüne alınd1ğında; Hall ve arkadaşlarının (53) 2012 yllında yaptığı ve 19 çalışmanın değerlendirildiği sistematik bir derleme çalışmasinda; mama ile beslenen bebeklerde kazein hidrolize mamalar ve anne sütü alan bebeklerde düşük allerjen içeren anne diyeti gibi besinsel yaklaşımlar konusunda bazı olumlu bilimsel verilerin mevcut olduğu, fakat simethicone, dicyclomine hydrochloride, cimetropium bromide, laktaz ve davranışsal tedavilerin etkinliği konusunda yeterli kanıtın olmadığı bildirilmiştir. Avrupa Pediatrik Gastroenteroloji, Hepatoloji ve Beslenme Derneği (ESPGHAN) 2013 yllında infantil kolik tedavisi ile ilgili öneriler düzenlemiştir. Kolik geçici bir durum olduğundan ebeveyne danışmanlık ve rahatlatmanın en önemli yaklaşım olduğu, farmakolojik tedaviler için yeterli kanıtın bulunmadığı, anne sütü alan kolikli bebeklerde bebeğe hipoallerjenik diyet önerilmemesi gerektiği, anne sütü alan ve dört ayın altında olan ciddi ve iyileşmeyen kolik olgularında ve eğer inek sütü allerjisinin diğer bulgular1 (diare, kusma, egzema vb) bebekte varsa anneye hipoalerjen diyet önerilebileceği, bebekte düzelme olursa ileri testlerle inek sütü allerjisi tanısının kesinleştirilmesi gerektiği, soya bazlı ve laktozsuz mamaların, laktaz enziminin, probiyotiklerin, bitkisel ve manipulatif tedavilerin önerilmesi için yeterli kanıt olmadığı bu öneriler içinde yer almaktadir (54).

Sonuç olarak; infantil kolik etiyolojide kuşkulanılan durumlar ne olursa olsun; genellikle kendi kendini sınırlayan ve diğer ciddi semptomların olmadığ1 bir süreçtir. Tanıda, bu dönemde görülebilen diğer hastalıkların ve sorunların ayırıcı tanısının yapılması çok önemlidir. Şu ana kadar yapılan çalışmalarda; infantil koliğin tedavisinde etkinliği kesin olarak kanıtlanmış bir tedavi yöntemi bulunmamakta olup ailelerin koliğin genellikle geçici bir durum olduğu konusunda bilgilendirilmesi, rahatlatılması ve desteklenmesi çok önemlidir. 


\section{KAYNAKLAR}

1. Newman JD. Neural circuits underlying crying and cry responding in mammals. Behavioral Brain Resarch 2007;182:155165.

2. Hiscock H, Jordan B. Problem crying in infancy. Med J Aust 2004;181:507-512.

3. Fleisher DR. Infant colic. In: Faure C et al. editors. Pediatric Neurogastroenterology: Gastrointestinal Motility and Functional Disorders in Children, Clinical Gastroenterology, DOI 10.1007/978-1-60761-7099_31, New York: Springer Science Business Media; 2013. p. 347-354.

4. Kaley F, Reid V, Flynn EG. The psychology of infant colic: a review of current research. Infant Mental Health J 2011;32: 526-541.

5. Wessel MA, Cobb JC, Jackson EB, et al. Paroxysmal fussing in infancy, sometimes called colic. Pediatrics 1954;14:421-435.

6. Milla P, Hyman PE, Benninga M, et al. Infant colic. Functional gastrointestinal disorders-Rome III. McLean, VA: Degnon Associates, Inc.; 2006. p. 699-7703.

7. Akhnikh S, Engelberts AC, van Sleuwen BE, et al. The excessively crying infant: etiology and treatment. Pediatric Annals 2014;43:e69-e75.

8. Engler AC, Etzioni T, Pillar G. Sleep and Colic. In: Sheldon SH, Kryger MH, Ferber R, Gozal D editors. Principles and Practice of Pediatric Sleep Medicine. 2nd ed. New York: Elsevier Saunders; 2014. p. 77-82.

9. Lucassen PLBJ, Assendelft WJ, van Eijk JT, et al. Systematic review of the occurrence of infantile colic in the community. Arch Dis Child 2001;84:398-403

10. Burns AJ, Thapar N. Developmental and postnatal changes in the enteric nervous system. J Pediatr Gastroenterol Nutr 2013;57(Suppl 1):S4-8.

11. Roberts DM, Ostapchuk M, O’Brien JG. Infantile colic. Am Fam Physician 2004;70:735-739.

12. Shamir R. Infant crying, colic, and gastrointestinal discomfort in early childhood: a review of the evidence and most plausible mechanisms JPGN 2013;57:S1-S2.

13. Indrio F, Riezzo G, Di Mauro A, et al. Gut motility alterations in neonates and young infants: relation to colic? J Pediatr Gastroenterol Nutr 2013;57(Suppl 1):S9-11.
14. Rhoads JM, Fatheree NY, Norori J, et al. Altered fecal microflora and increased calprotectin in infants with colic. J Pediatr 2009;155:823-882.

15. Heine RG. Cow's-milk allergy and lactose malabsorption in infants with colic. J Pe diatr Gastroenterol Nutr 2013;57(Suppl 1):S25-7.

16. Nocerino R, Pezzella V, Cosenza L, et al. The controversial role of food allergy in infantile colic: evidence and clinical management. Nutrients 2015;7: 2015-2025.

17. Heine RG. Gastroesophageal reflux disease, colic and constipation in infants with food allergy. Curr Opin Aller Clin Immunol 2006;6:220-222

18. Verduci E, Arrizza C, Riva E, et al. Microbiota and infantile colic: what's new? Int J Probiot Prebiot 2013;8:25-28.

19. De Weerth C, Fuentes S, de Vos WM. Crying in infants. Gut Microbes 2013;4: 416-421.

20. Indrio F, Riezzo G, Raimondi F, et al. Mic robiota involvement in the gut-brain axis. J Pediatr Gastroenterol Nutr 2013;57 (Suppl 1):S11-5.

21. Ha-Vinh Leuchter R, Darque A, Hüpp PS. Brain maturation, early sensory processing and infant colic. J Pediatr Gastroenterol Nutr 2013;57(Suppl 1):S18-25.

22. Milidou I, Sondergaard C, Sondergaard Jensen M, et al. Gestational age, small for gestational age, and infantile colic. Paediatr Perinat Epidemiol 2014;28:138-145.

23. Canivet CA, Ostergren PO, Rosen AS, et al. Infantile colic and the role of trait anxiety during pregnancy in relation to psychosocial and socioeconomic factors. Scand J Public Health 2005;33:26-34.

24. Kurth E, Kennedy HP, Spichiger E, et al Crying babies, tired mothers: What do we know? A systematic review. Midwifery 2011;27:187-1

25. Vik T, Grote V, Escribano J, European Childhood Obesity Trial Study Group, et al. Infantile colic, prolonged crying and maternal postnatal depression. Acta Paediatr 2009;98:1344-1348.

26. Reijneveld SA, van der Wal MF, Brugman $\mathrm{E}$, et al. Infant crying and abuse. Lancet 2004;364:1340-1342.
27. Fujiwara T, Barr RG, Brant R, et al. Infant distress at five weeks of age and caregiver frustration. J Pediatr 2011;159:425-430.

28. Clifford TJ, Campbell MK, Speechley KN, et al. Sequelae of infant colic: evidence of transient infant distress and absence of lasting effects on maternal mental health. Arch Pediatr Adolesc Med 2002;156: 1183-8.

29. Di Lorenzo C. Impact of early life events on pediatric functional gastrointestinal disorders. J Pediatr Gastroenterol Nutr 2013;57(Suppl 1):S15-8.

30. Heine RG. Gastrointestinal food allergy and intolerance in infants and young children. J Pediatr Gastroenterol Nutr 2013; 57(Suppl 1):S38-41.

31. Indrio F, Di Mauro A, Riezzo G, et al. Infantile colic, regurgitation, and constipation: an early traumatic insult in the development of functional gastrointestinal disorders in children? Eur J Pediatr 2015; 174:841-842

32. Wolke D, Rizzo P, Woods S. Persistent infant crying and hyperactivity problems in middle childhood. Pediatrics 2002;109: 1054-1060.

33. Rao MR, Brenner RA, Schisterman EF, et al. Long term cognitive development in children with prolonged crying. Arch Dis Child Fetal Neonat Ed 2004;89:989-992.

34. Gelfand AA. Infant Colic. Semin Pediatr Neurol 10.1016/j.spen.2015.08.003 DOI: http://dx.doi.org/10.1016/j.spen.2015.0 8.003

35. Gelfand AA, Goadsby PJ, Allen IE. The relationship between migraine and infant colic: A systematic review and meta-analysis. Cephalalgia 2015;35:63-72.

36. Freedman SB, Al-Harthy N, Thull-Freedman J. The crying infant:Diagnosis testing an frequency of serious underlying disease. Pediatrics 2009;123:841-848.

37. Savino F, Benetti S, Ceratto S. Infantile colic: from symptoms to diagnosis - A practical approach. J Symptoms and Signs 2013;2:248-252

38. Savino F, Ceratto S, De Marco A, et al. Looking for new treatments of infantile colic Italian J Pediatr 2014,40:53.

39. NICE. Diagnosis and assessment of food allergy in children and young people in primary care and community settings: CG116 [online]. 2011. Available at: www.nice.org. uk/guidance/CG116 
40. Bhatia J, Greer F; American Academy of Pediatrics, Committee on Nutrition. Use of soy protein-based formulas in infant feeding. Pediatrics 2008;121:1062-1068.

41. Chau K, Lau E, Greenberg S, et al. Probiotics for infantile colic: randomized, double-blind placebo-controlled trial investigating lactobacillus reuteri DSM 17938. J Pediatr 2015;166:74-78.

42. Sung V, Hiscock H, Tang MLK, et al. Treating infant colic with the probiotic Lactobacillus reuteri: double blind, placebocontrolled randomised trial. BMJ 2014; 348:g2107.

43. Anabrees J, Indrio F, Paes B, et al. Probiotics for infantile colic: a systematic review BMC Pediatrics 2013,13:186.

44. Critch JN. Infantile colic: Is there a role for dietary interventions? Paediatr Child Health 2011;16:47-49.
45. Waddell L. Management of infantile colic an update. J Fam Health Care 2015;23:17-22.

46. Markestad T. Use of sucrose as a treatment for infant colic. Arch Dis Child 1997;76:356-358.

47. Aviner S, Berkovitch M, Dalkian H, et al. Use of a homeopathic preparation for infantile colic and an apparent life-threatening event. Pediatrics 2010;125:e318-323.

48. Perry R, Hunt K, Ernst E. Nutritional supplements and other complementary medicines for infantile colic: a systematic review. Pediatrics 2011;127:720-733.

49. Ernst E. Chiropractic spinal manipulation for infant colic: a systematic review of randomised clinical trials. Int J Clin Prac 2009;63:1351-1353.

50. Dobson D, Lucassen PL, Miller JJ, et al. Manipulative therapies for infantile colic. Cochrane Database Syst Rev
2012;12:CD004796.
51. Skjeie H, Skonnord T, Fetveit A, et al. Acupuncture for infantile colic: a blindingvalidated, randomized controlled multicentre trial in general practice Scand J Primary Health Care 2013;31:190-196.

52. van Sleuwen BE, Engelberts AC, BoereBoonekamp MM, et al. Swaddling: a systematic review. Pediatrics 2007;120:e10971106.

53. Hall B, Chesters J, Robinson A. Infantile colic: A systematic review of medical and conventional therapies. J Paediatr and Child Health 2012;48:128-137.

54. Bellaiche M, Levy M, Jung C. Treatments for infant colic. JPGN 2013;57:S27-S29. 